\title{
WILLIAM BUTLER YEATS
}

\author{
A. D. HOPE
}

TO HAVE FOUND AT LAST that noble, candid speech

1 In which all things worth saying may be said, Which, whether the mind asks, or the heart bids, to each Affords its daily bread;

To have been afraid neither of lust nor hate, To have shown the dance, and when the dancer ceased, The bloody head of prophecy on a plate Borne in at Herod's feast ;

To have loved the bitter, lucid mind of Swift, Bred passion against the times, made wisdom strong ; To have sweetened with your pride's instinctive gift The brutal mouth of song;

To have shared with Blake uncompromising scorn For art grown smug and clever, shown your age The virgin leading home the unicorn And loosed his sacred rage -

But more than all, when from my arms she went That blessed my body all night, naked and near, And all was done, and order and content Closed the Platonic Year,

Was it not chance alone that made us look Into the glass of the Great Memory And know the eternal moments, in your book, That we had grown to be? 